\title{
Floristic Survey of Meethirigala Forest Reserve in Gampaha District
}

\author{
J.D. Kalubowila ${ }^{1}$, B.M.P. Singhakumara ${ }^{1}$ and R.A.M.P.M. Rajathewa ${ }^{2}$ \\ ${ }^{l}$ Department of Forestry and Environmental Science, University of Sri Jayewardenepura, \\ Nugegoda, Sri Lanka \\ ${ }^{2}$ Environmental Consultants, Education and Rehabilitation Organization (ECERO), \\ Gampaha, Sri Lanka
}

Date Received: 05-05-2020

Date Accepted: 26-06-2020

\begin{abstract}
Meethirigala forest reserve consists of approximately 384 ha. It is the largest forest reserve in Gampaha District managed by the Forest Department. It has different topographic positions such as ridges, midslopes and valley areas close to the Kelani River. The present study was conducted to enumerate plant species found in all three topographic positions of the reserve. Plots were demarcated purposively to sample woody perennials equal or greater than $5 \mathrm{~cm}$ dbh (diameter at breast height) in 18 plots $(5 \times 100 \mathrm{~m}$, rectangular shape). Seedlings greater than $1 \mathrm{~m}$ tall were sampled in 18 plots $(5 \times 5 \mathrm{~m})$. Shannon diversity indices were calculated to compare dominance of particular species in different topographic positions. A total of 360 individuals of woody perennials belonging to 73 species in ridge, 368 individuals of woody perennials belonging to 100 species in midslope and 272 individuals of woody perennials belonging to 69 species in valley were recorded. And 132, 123 and 100 individuals of seedlings were enumerated in ridge, midslope and valley respectively. In ridge 58 generas, 28 families, in midslope 83 generas, 35 families and, in valley 68 generas, 29 families were observed. 28 species were found in all three different altitudes of the reserve. Forest species in study sites gave a total of 138 plant species belonging to 113 tree species, 11 climber species, 14 shrub species, 109 generas and 46 families. Of this total 138 species, 34 (25\%) species are endemic to Sri Lanka. Highest endemism was recorded in the ridge (41.6\%). Stratification of the ridge showed a very similar pattern to a Dipterocarp forest type. Highest diversity was recorded in midslope (1.7290) and lowest recorded in ridge (1.5626) of the forest. 18 threatened species were observed (3-Endangered and 15-vulnerable species). As a conclusion, Meethirigala forest reserve can be considered as an important refuge for wet zone forest species.
\end{abstract}

Keywords: forest reserve, ridge, midslope, valley, species

\section{Introduction}

Sri Lanka together with the Western Ghats in Southern India, is a one of the currently recognised, thirty five global hotspots for biological diversity (Ariyarathne et al., 2017). These 35 hotspots define regions where $43 \%$ of vertebrates (including $60 \%$ of threatened mammals and birds), and $80 \%$ of all threatened amphibians (Mittermeier et al., 2011; Williams et al., 2011) survive within habitat covering just $17.3 \%$ of the Earth's surface. To qualify as a hotspot, a region must meet two criteria: it must contain at least 1,500 species $(>0.5$ percent of the world's total) of vascular plants as endemics; and it must have lost at least $70 \%$ of its original habitat due to the impacts of human activities (Green et al., 2009). Studies on floristic composition is essential for the management of an area for habitat and ecosystem conservation.

*Correspondence: jdkalubowila@gmail.com

Tel: +94717523070

(C) University of Sri Jayewardenepura 
The present land form of Sri Lanka is the result of millions of years of weathering by rain and wind, as well as movement of the earth's crust. The topography of Sri Lanka is remarkably varied for itsmall area, with coastal plains, lowland hills and a mountainous interior. This variation is reflected in the complexity of the island's diversity of natural plant communities and crops (Ashton et al., 1997). Sri Lanka's forest cover is diminishing rapidly and now stands at less than $20 \%$ of its pre-colonial extent (Figure 1) (Mattsson et al., 2012; Perera, 2001). Legg and Jewell (1995), noted additionally that 23\% of the island's forest cover consisted of 'sparse' (secondary) forest. Most recently, Perera and Tsuchiya (2009), in their study of forest cover in south-eastern Sri Lanka (an extent of $11,800 \mathrm{~km}^{2}$ including the Yala National Park Complex and its surroundings), found that in the two decades spanning 1987-2006, forest cover halved ( $40.2 \%$ to $20.6 \%$ ) while homestead vegetation doubled (16.4\% to $30.1 \%$ ) and mixed scrub-dominant vegetation increased by almost $20 \%$ (34.3\% to $41.4 \%)$.

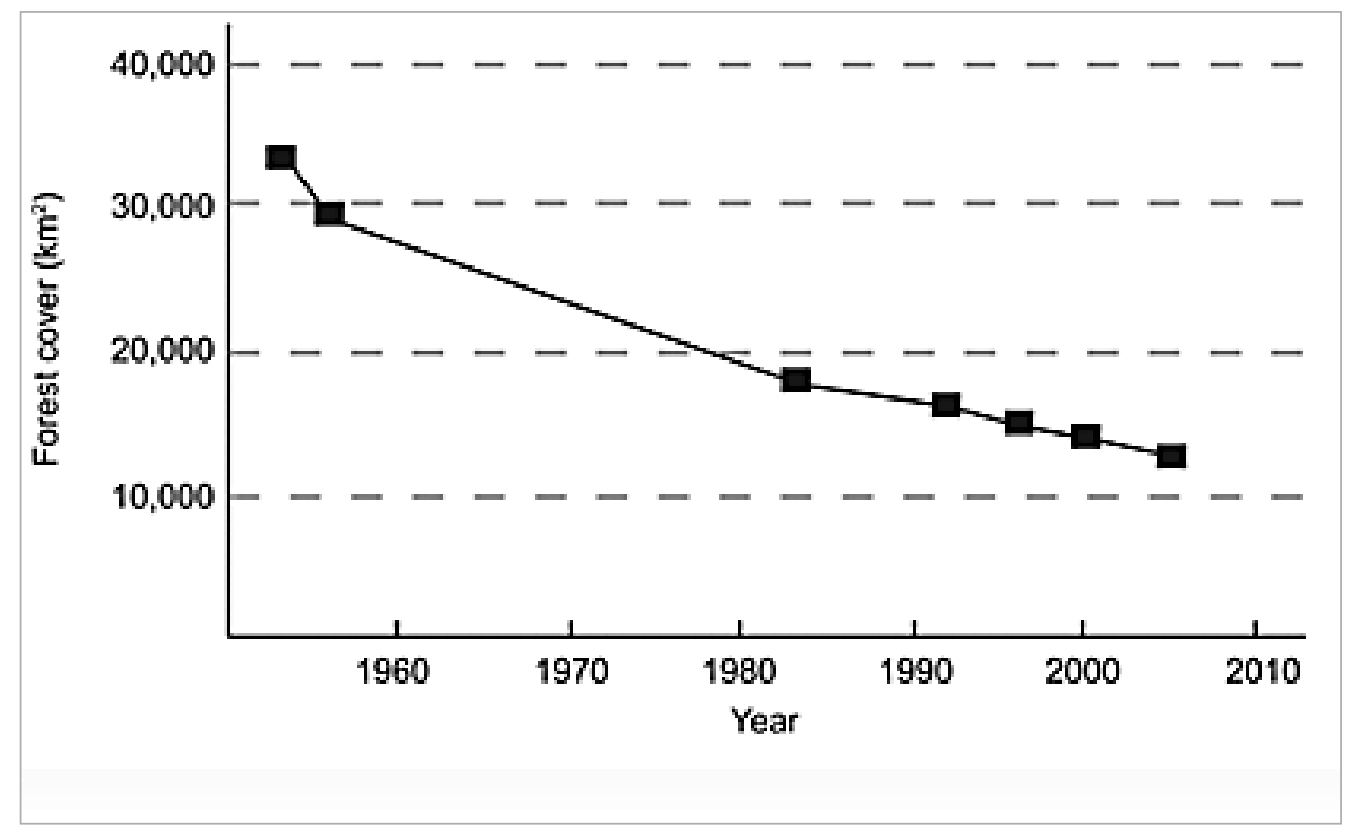

Figure 1. The decline of closed-canopy forest cover in Sri Lanka since 1950 (Mattsson et al., 2012).

Gampaha District, forest cover occupies approximately $0.56 \%$ of the total land area in Western province. It includes 428 ha $(0.31 \%)$ of natural forest and 345 ha $(0.25 \%)$ of plantations (Bambaradeniya, 2008). As per the National Red List of Sri Lanka (2012), this country has 3,154 species with 894 endemic species of Angiosperms. Those belongs to 185 families. Declines in populations, together with declines in areas of occupancy, extents of occurrence and/or the quality of habitat, determine the conservation status of the vast majority of the endemic Sri Lankan species that have been assessed as threatened as part of the IUCN's Red Listing process (IUCN, 2001). Currently Sri Lanka has over 1,385 flowering threatened plant species among the 3,154 species assessed so far (The National Red List, 2012). Information on the threatened status of species in other plant groups are lacking. Family Anacardiaceae has $46.7 \%$ of endemics was considered as nationally threatened during the National Red listing in 2012. The conservation of Sri Lanka's flora has received much less attention than its fauna, the data in Dassanayake and Fosberg (1980-1991), that as many as 61 endemic flowering-plant species (including 23 trees) had not been collected in the preceding 50 years, having passed almost unnoticed. The objectives of this study, to examine floristic composition and diversity of Meethirigala forest reserve and to record endemic and threatened plants of the Meethirigala forest reserve. 


\section{Methodology}

\subsection{Site selection}

Study site was selected based on the reconnaissance survey. Selected forest is the largest forest reserve in Gampaha district managed by the Forest Department, Sri Lanka. Reason for the selection of this site was according to the available information this contain comparatively high amount of natural vegetation (Figure 2). Meethirigala forest reserve was declared by the Forest Department on 4th August 1973. This forest patch consists of approximately 384 ha according to the Survey Department. A public bus route runs across this reserve dividing the forest into two large portions. The Kelani river flows along the southern boundary of the Gampaha district and number of small tributaries flow within the Meethirigala forest reserve finally draining into the Kelani river. Meethirigala forest patch is surrounded by home gardens, public roads, paddy fields and rubber plantations. Within this reserve there is a Buddhist monastery that has been there since 1968. The monastery is occupied by the hermitage Buddhist monks and therefore not much human activities take place and hence with no illegal human encroachments. This forest reserve has been utilised by the villagers in many ways to collect fuel wood, medicines, chena cultivation etc. In the Meethirigala forest reserve, some areas can be recognised as disturbed while rest of the reserve is relatively undisturbed.

\subsection{General geography and climate}

Topographically, the area is divided into plains and highlands with an elevation ranging from 30$450 \mathrm{~m}$, below $30 \mathrm{~m}$ altitude is considered as the plains, with little undulating lands. The elevation ranging from 150-450 $\mathrm{m}$ of the Meethirigala and Kiridiwela are considered as highlands. The average rainfall of 2,000-2,500 $\mathrm{mm}$ and mean annual temperature is $32^{\circ} \mathrm{C}$ with little fluctuations annually (Suraweera et al., 1999).

\subsection{Data collection}

Size of the plots were pre-determined based on reconnaissance survey. $5 \times 100 \mathrm{~m}$ plots were laid out at each sampling location to sample woody perennials that equal or exceed $5 \mathrm{~cm} \mathrm{dbh.} 5 \times 5 \mathrm{~m}$ plots were laid out at each sampling location to sample seedlings greater than $1 \mathrm{~m}$ in height. Eighteen sample plots for both woody perennials and seedlings were sampled. Size of the plots were different for woody perennials $(5 \times 100 \mathrm{~m})$ and seedlings $(5 \times 5 \mathrm{~m})$. Sample plots distributed in disturbed and undisturbed sites are shown in Table 1. Plots were demarcated purposively to sample the vegetation. Plot is $100 \mathrm{~m}$ long and $5 \mathrm{~m}$ wide. It was measured along the center line using a nylon rope. Dbh and height of each plant species that equal or exceed $5 \mathrm{~cm}$ dbh was recorded. Dbh was recorded using dbh tape and height was visually estimated. Plants that have some special identification characters were identified with the help of field experts. The National Red List 2012 of Sri Lanka was used to find out the endemic species and No. 22 of 2009 Flora and fauna protection ordinance (amendment) was used to find out protected status of the recorded species.

Table 1: Distribution of sample plots.

\begin{tabular}{lcccccc}
\hline \multirow{2}{*}{ No of Plots } & \multicolumn{3}{c}{ Disturbed } & \multicolumn{3}{c}{ Undisturbed } \\
\cline { 2 - 7 } & Valley & Midslope & Ridge & Valley & Midslope & Ridge \\
\hline $18(5 \times 100 \mathrm{~m})$ & 1 & 2 & 0 & 5 & 4 & 6 \\
$18(5 \times 5 \mathrm{~m})$ & 1 & 2 & 0 & 5 & 4 & 6 \\
\hline
\end{tabular}

Tree species diversity index by relating the total number of species to the total number of individuals in the sample. Shannon Wiener diversity index was used for comparative purposes (Dong and $\mathrm{Ji}, 2011$ ). 
Diversity:

$$
H^{\prime}=-\sum P i \times \log (P i)
$$

where: $P i=$ Proportional abundance

$P i=$ No. of individuals of a particular species/No. of all individuals of all species

Evenness:

$$
\left(J^{\prime}\right)=H^{\prime} / H^{\prime} \max
$$

where: $H^{\prime} \max =\log S$

$S=$ No. of species found in the stand

$$
\text { Dominance }=1-J
$$

Estimated Profile Diagrams were prepared for the three topographic positions. For this purpose, only vegetation up to $5 \mathrm{~m}$ on either side of the line was recorded. Seedlings of greater than 1 meter in height the extent and location of these groups of seedlings was noted rather than each individual. The names of all tree and shrub species was recorded. Total height was recorded to the nearest meter.

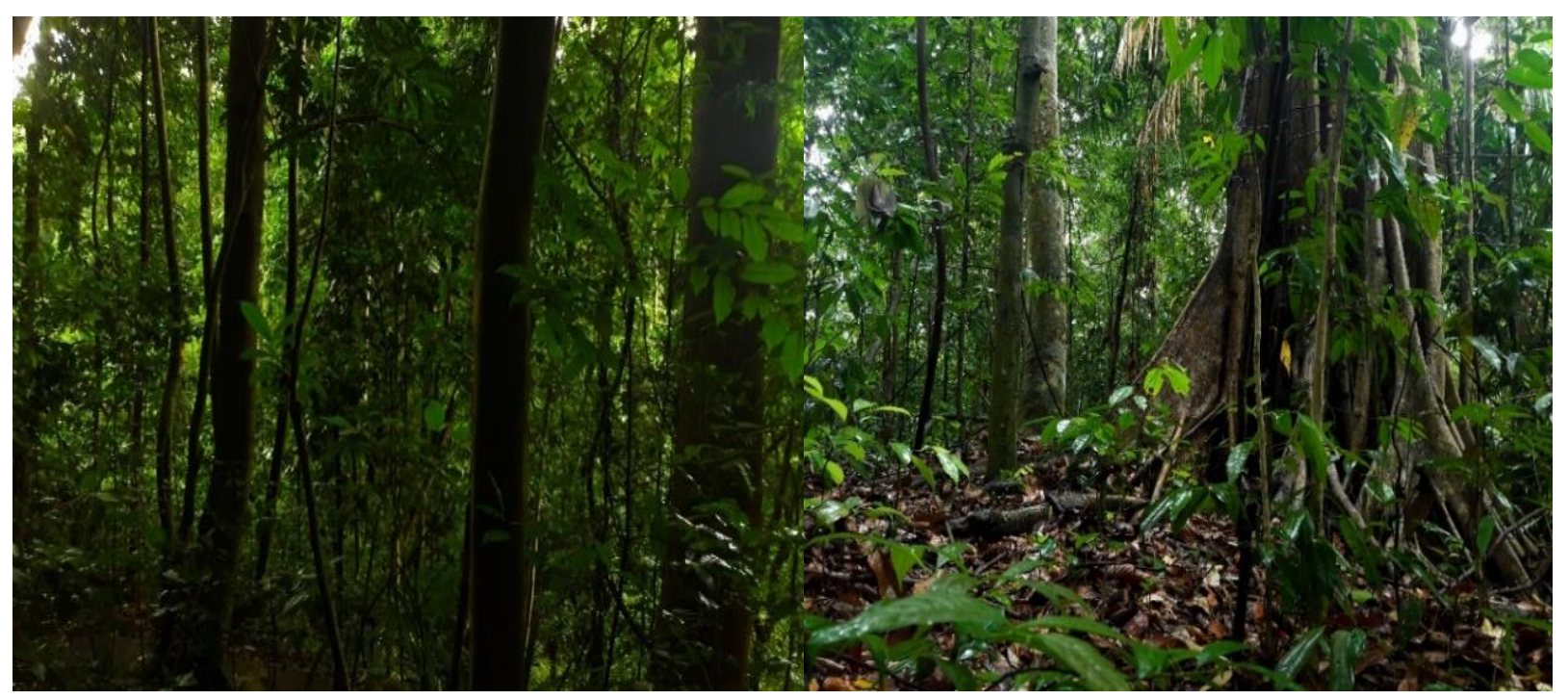

Fig

ure 2. Forest interior of Meethirigala forest reserve.

\section{Results}

Clear Stratification was observed in forest ridge. Trees with average diameter of $15.7 \mathrm{~cm}$ (six $5 \times 100 \mathrm{~m}$ plots) in ridge. Canopy layer occurs 35-40 m in height. Emergent layer was seen over the canopy layer. Below the canopy is lower story of medium sized trees principally comprised, between 25$30 \mathrm{~m}$ in height (sub-canopy layer). Dipterocarpus zeylanicus was found as most common species in ridge, other than that Artocarpus nobilis, Chaetocarpus castanocarpus, Shorea sp, Myristica dactyloides, Garcinia quaesita, Gyrinops walla, Chrysophyllum roxburghii and Bridelia mooni. D. zeylanicus was $9.8 \%$ from the total number of species found in ridge and major tree species contribute to form canopy layer. Aporusa lanceolate, Mallotus rhamnifolius, Dillenia retusa and G. walla was found as most common seedlings in ridge. Average dbh of trees in midslope was $16 \mathrm{~cm}$ (six $5 \times 100 \mathrm{~m}$ plots). 
The height of trees was low in midslope than ridge, but the dbh of trees was higher than the ridge. Most common tree species were D. zeylanicus, A. nobilis, Bridelia retusa, and Vitex altissima. Seedlings found in midslope were Ixora coccinea, Osbeckia aspera, Pagiantha dichotoma, Gaertnera vaginans, Symplocos cochinchinensis, A. nobilis and Acronychia pedunculata. Average dbh was $12.4 \mathrm{~cm}$ in valley ( ix $5 \times 100 \mathrm{~m}$ plots). Valley has trees with lowest height and dbh compared to ridge and midslope. The most common species were, S. cochinchinensis, Caryota urens, Macaranga peltata, Humboldtia laurifolia, Syzygium caryophyllatum and D. retusa.

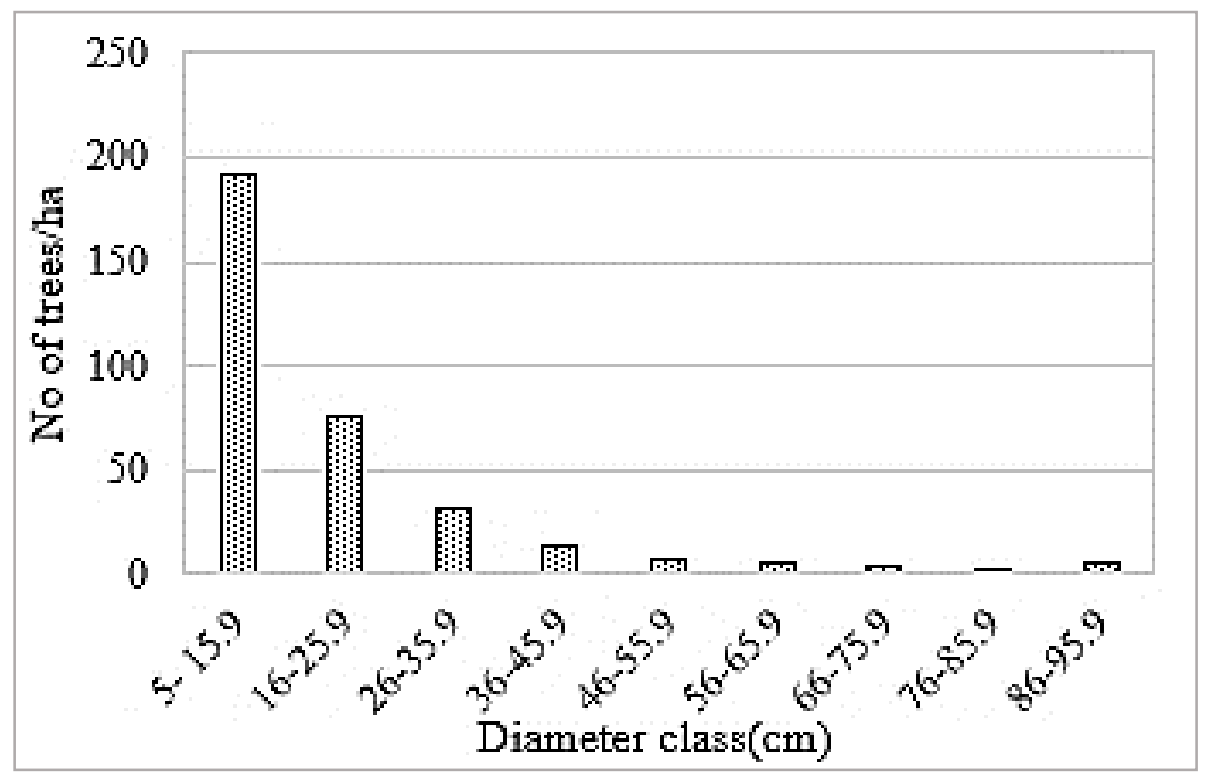

Figure 3. Diameter-class distribution of tree species.

A total of 1,012 individuals $(\mathrm{dbh} \geq 5 \mathrm{~cm})$ were recorded in eighteen $5 \times 100 \mathrm{~m}$ plots. A total of 355 individuals (seedlings $>1 \mathrm{~m}$ tall) were recorded in eighteen $5 \times 5 \mathrm{~m}$ plots. 368,360 and 272 individuals were recorded in $5 \times 100 \mathrm{~m}$ plots and 132, 123 and 100 individuals were recorded in $5 \times 5 \mathrm{~m}$. It was found that there were 138 species in Meethirigala forest reserve and out of that 34 species are endemic. Endemic percentage of identified species was 25\%. Ninety-seven species were indigenous, and seven species were exotic and three species were identified up to generic level. List (botanical name, family, life form, taxonomic status and conservation status) of plants found in the study area have been given in Appendix (1). Total 138 species distributed in three different altitudes of the reserve as follows. Only in ridge-13, only in midslope-28, only in valley-18, ridge and midslope-26, ridge and valley-4, midslope and valley-18, all three positions-29 species were observed. Eighteen threatened species (appendix 2) were found and out of that Semicarpus marginata, Salacia oblonga and Zanthoxylum rhesta was found as endangered species. Highest endemism (41.6\%) was found in ridge and lowest $(26.3 \%)$ found in valley. Diameter class distribution of selected tree species demonstrated various patterns of distributions. Low dbh classes have higher species density distribution than the higher dbh classes (Figure 3 ).

\subsection{Estimated profile diagrams}

Diverse vertical structure of forest provided a variety of environmental conditions from strata in the canopy to the forest floor shown in Figure 4-6. Diagrams clearly shows that different plant communities in three different altitudes of the forest. 


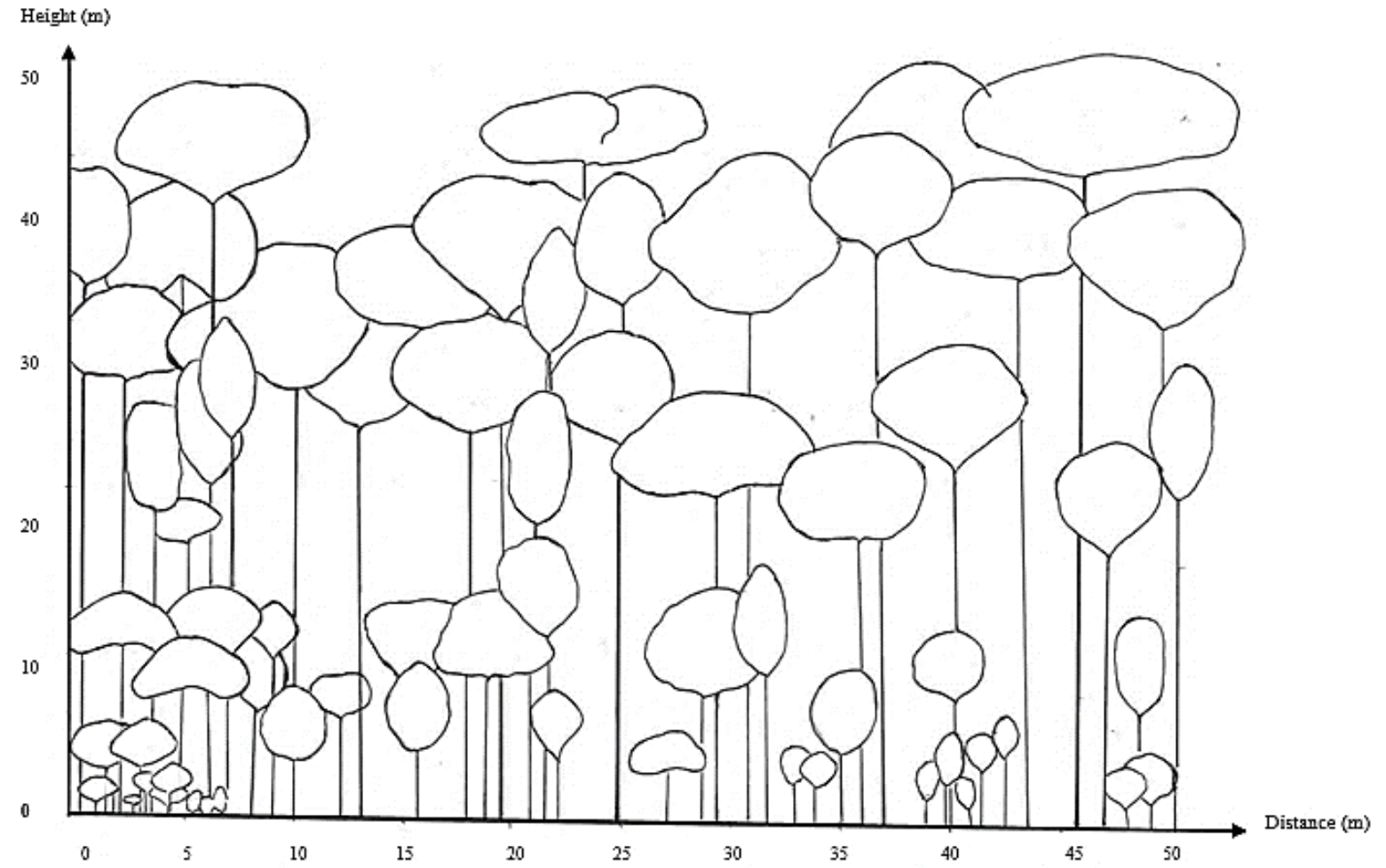

Figure 4. Vertical distribution of trees in ridge.

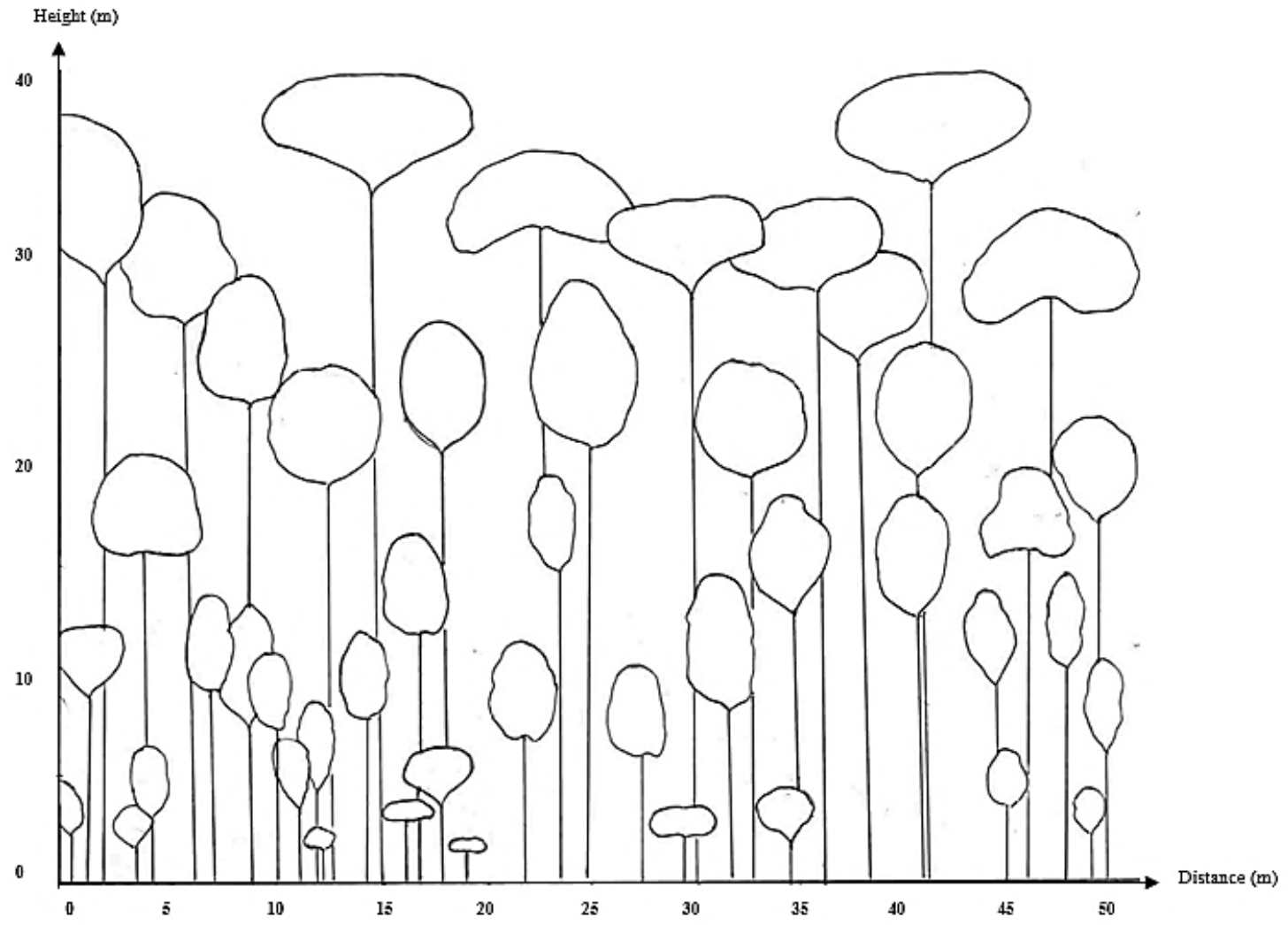

Figure 5. Vertical distribution of trees in mid-slope. 


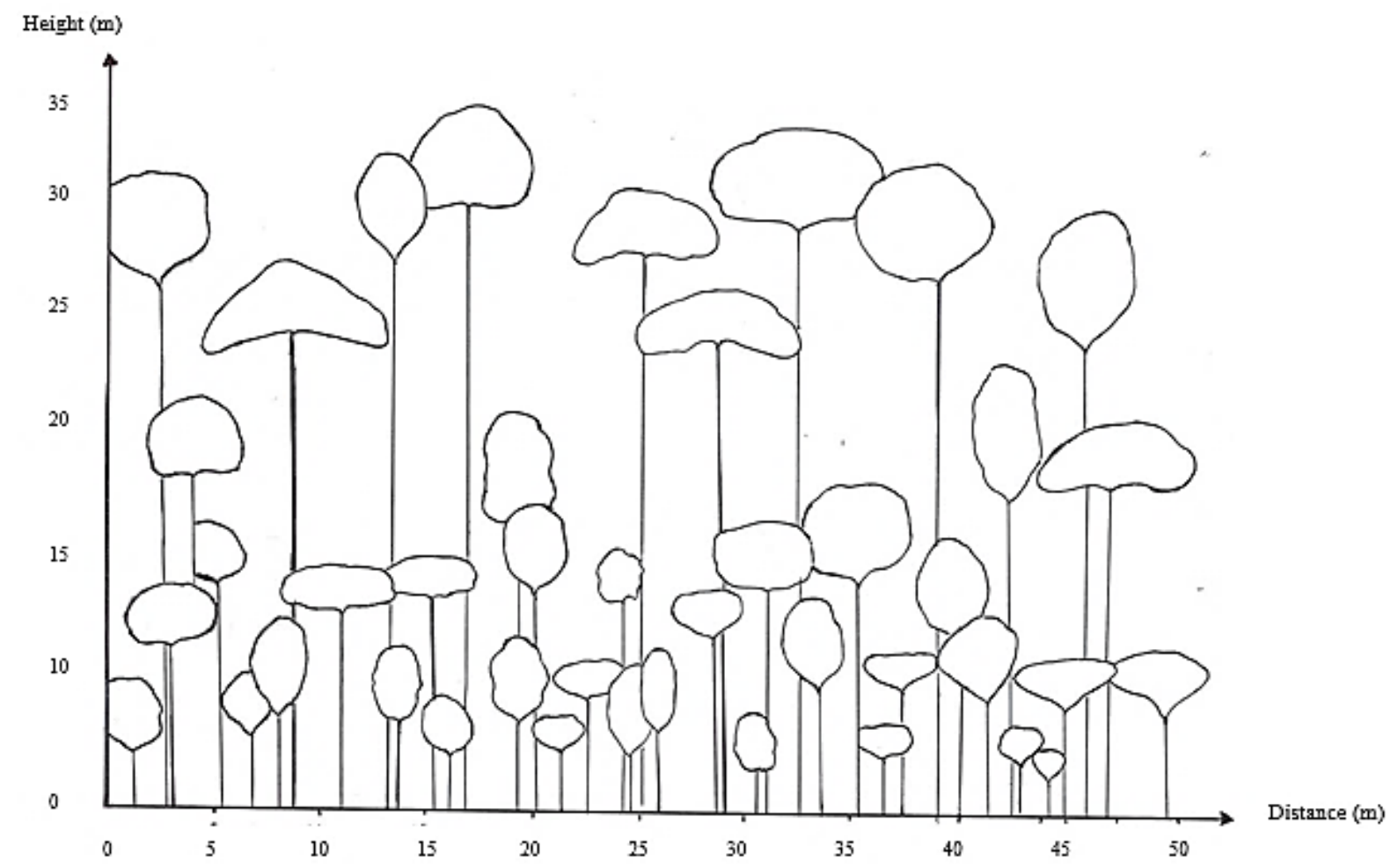

Figure 6. Vertical distribution of trees in valley.

\section{Discussion}

Stratification was clear in ridge of the forest. It has been recognised that the forest canopy has a complex structure that is significant for environmental interactions, regeneration, growth, and biotic habitat. Not only is the structure variously complex, but also there are many ways to conceptualise that complexity. Yet the persistent theme when considering the structure of canopies continues to be that of stratification. Oversized trees reaching heights of more than $45 \mathrm{~m}$ tall was found in the Emergent Layer. Together, the top branches and leaves from emergent layer trees form a mushroom shape above the thick canopy layer below. The major tree species contribute to form canopy layer, D. zeylanicus and it was the dominant tree species in ridge area. Understory was quite dark. Because of the lack of sunlight that is able to penetrate into the forest floor. Ground was covered with leaf litter and few ground layer species was seen. In this study Dipterocarpaceae is the most dominat family followed by Annonaceae, Euphorbiaceae, Moraceae and Clusiaceae in ridge. Apocynaceae is the most dominant family in midslope followed by Moraceae, Dipterocarpaceae, Euphorbiaceae and Anacardiaceae. Altitude of Meeethirigala FR is affected the dominace of species while the aspect of vegetation affected only the distribution of the species. Natural regeneration is the process by which woodlands are restocked by trees that develop from seeds that fall and germinate in situ. Important factor in natural regeneration is the size of gaps created in forest. Good regeneration of primary forest species takes place in those small gaps created by naturally dying trees within the primary forest. Secondary species rarely invade those naturally formed gaps to compete successfully within the primary species (Gunatilleke and Gunatilleke, 1984). Natural regeneration has been occurred in ridge, because seedlings of woody perennials has been observed. Seedlings of D. zeylanicus and G. walla was observed.

In the present study 34 endemic species was recorded, out of that 29 tree species, 4 shrub species and 1 climber species. Endemism represents a unique step in the process of evolution, which could be sustained only in the locality concerned depending on the environmental quality, habitat is very much 
important. There was a large population of Zeuxine regia which is an endemic species belongs to the family Orchidaceae (Figure 7). It is an endangered medicinal plant. It has not been recorded earlier in the Gampaha District. During the ecological study in Kanneliya MAB reserve and peak wilderness sanctuary it was observed that the most common families associated with Z. regia were Ebanaceae, Anacardiaceae and Dipterocarpacea, and species associated with Z. regia were, Anysophyllea cinnamoides, Mangifera indica, Shumacheria castaneifolia, Gnidia gaertn and S. cochinchinensis (Hewage, 2011). In the present study it was observed that A. cinnamoides and S. cochinchinensis associated with $Z$. regia. The reason that certain species grow together in a particular environment will usually be, because they have similar requirements for existence in terms of environmental factors. Species diversity of lowland was slightly higher than sub montane and upper montane forests. Lowland diversity is higher and upper montane has lower diversity in peak wilderness sanctuary (Singhakumara, 1995). Floristic similarity between locations is closely related to the geographical distances of them. These slight differences of the diversity may be due to the elevation changes.

Alstonia macrophylla was observed in three topographic positions. It shows some invasive characteristic inside the forest. The source of introduction is mainly from wet and intermediate forests and affected to the secondary forests. Invasive species are generally exotic or alien species having the ability to compete with and replace native species in natural habitats, thereby threatening native biological diversity. They have special characteristics that enable them to spread rapidly and aggressively and compete with native flora and fauna, to form a dense population that interferes with the natural development of biotic communities. Meethirigala forest has cleared for several plantations is the main reason for spreading invasive species.

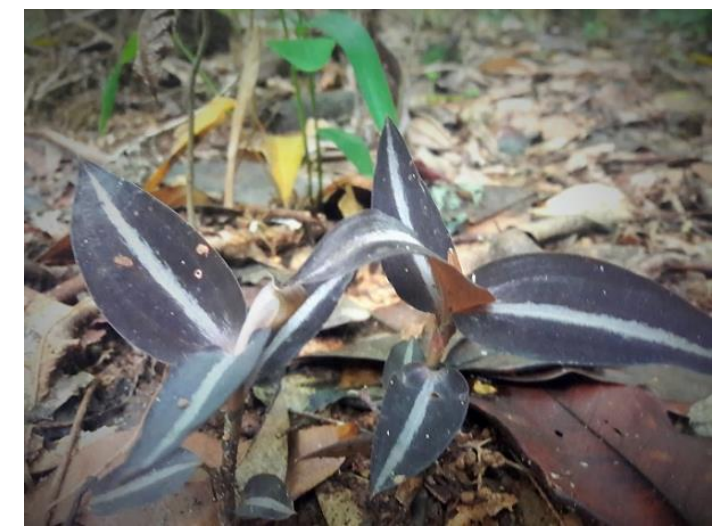

Figure 7. Z. regia in the Meethirigala forest reserve.

\section{Conclusion}

Meethirigala forest reserve is rich and diverse in floristic composition and distribution (a total of 138 floristic species) and it is an isolated fragmented forest patch that should be protected as a biodiversity refugium in the wet zone which could enhance the floristic diversity and also the viability of plant species population. Findings of the study could be useful in preparation of conservation plans for the Meethirigala forest reserve. Since this study has found endangered and threatened species in the forest. The finding from this study may help government and other stakeholders in providing baseline information, supported by scientific evidence, which can further contribute to more informed policy and decision-making processes. Soil also can have considerable influence on tree species composition in different topographic levels in the forest. Therefore, soil quality in each site can be used as an indicator of floristic composition. Analysis of population structures for each individual tree species could provide more realistic and specific information for conservation measure. 


\section{References}

Ariyarathne, W.A.M.P., Yakandawala, D., Samuel, M.R. and Wijesundara, S., 2017. Evaluating the occurrence and conservation status of Sri Lankan species of Anacardiaceae. Ceylon Journal of Science, 46:59-67.

Ashton, M., Gunatilleke, C.V.S., Gunatilleke, I.A.U.N., de Zoysa, N. Dassanayake, M.D. and Wijesundara, S.A., 1997. A field guide to the common trees and shrubs of Sri Lanka. Wildlife Heritage Trust Publications (Pvt.) Ltd, Sri Lanka.

Bambaradeniya, C., 2008. Western province biodiversity profile and conservation action plan. Biodiversity Secretariat, Ministry of Environmental and Natural Resources, Sri Lanka.

Carlos, I.E., Omar, C. and Arantzazu, L.L., 2010. What factors affect diversity and species composition of endangered Tumbesian dry forests in Southern Ecuador. Biotropica, 43:15-22.

Dassanayake, M.D. and Fosberg, F.R., 1980-1991. Revised Handbook to the Flora of Ceylon, Volumes I-VII. Amarind Publishing Company, New Delhi.

Dong, J.Y. and Ji, H.K., 2011. Comparative evaluation of species diversity indices in the natural deciduous forest of Mt. Jeombong. Forest Science and Technology, 7:68-74.

Fauna and Flora Protection (amendment) Act, No. 22 of 2009. Parliament of the Democratic Socialist Republic of Sri Lanka.

Green, M.J., How, R., Padmalal, U.K.G.K. and Dissanayake, S.R.B., 2009. The importance of monitoring biological diversity and its application in Sri Lanka. Tropical Ecology, 50:41.

Gunatilleke, C.V.S. and Gunatilleke, I.A.U.N., 1984. Distribution of tree flora of a lowland hill forest in Sri Lanka. Biological conservation. 28:275-285.

Hewage, S., 2011. Studies on natural habitat and clonal propagation of Zeuxine regia (Iruraja) and Zeuxine flava (Sandaraja). M.Phil. Dissertation, University of Sri Jayewardenepura Nugegoda, Sri Lanka.

International Union for Nature Conservation (IUCN), 2001. IUCN Red List Categories and Criteria: Version 3.1. IUCN Species Survival Commission. IUCN, Gland, Switzerland and Cambridge, UK.

Legg, C. and Jewell, N., 1995. A 1:50,000-scale forest map of Sri Lanka: the basis for a national forest geographic information system. Sri Lanka Forester (Special Issue): 3-24

Mattsson, E., Persson, U.M., Ostwald, M. and Nissanka, S.P., 2012. REDD+ readiness implications for Sri Lanka in terms of reducing deforestation. Journal of Environmental Management. 100:29-40.

Mittermeier, R.A., Turner, W.R., Larsen, F.W., Brooks, T.M. and Gascon, C., 2011. Global biodiversity conservation: the critical role of hotspots. F.E. Zachos, J.C. Habel (Eds.), Biodiversity hotspots, Springer Publishers, London, pp. 3-22.

Perera, G.A.D., 2001. The secondary forest situation in Sri Lanka: A review. Journal of Tropical Forest Science, 13:768-785.

Perera, K. and Tsuchiya, K., 2009. Experiment for mapping land cover and its change in south eastern Sri Lanka utilizing 250 m resolution MODIS imageries. Advances in Space Research. 43:13491355.

Singhakumara, B.M.P., 1995. Floristic survey of Adam's Peak Wilderness, Sri Lanka, Forest Department, Sri Lanka.

Suraweera, A.V., Balagalle, W.G. Jayatilaka, K., Lakdusinghe, S., and Wijetunga, W.M.K., 1999. Gampaha district socio-cultural studies, Sri Lanka. (Publication in Sinhala), Department of cultural affairs.

The National Red List, 2012. Conservation Status of the Flora and Fauna. Biodiversity Secretariat of the Ministry of Environment and National Herbarium, Department of National Botanic Gardens of Sri Lanka. 
Williams, K.J., Ford, A., Rosauer, D.F., De Silva, N., Mittermeier, R., Bruce, C., Larsen, F. W., Margules, C., 2011. Forests of east Australia: the 35th biodiversity hotspot, Springer Publishers, London. pp. 295-310.

Appendix 1

\begin{tabular}{|c|c|c|c|c|}
\hline Botanical name & Family & Life form & $\begin{array}{l}\text { Taxonomic } \\
\text { status }\end{array}$ & $\begin{array}{c}\text { Conservation } \\
\text { status }\end{array}$ \\
\hline Strobilanthes adenophora & Acanthaceae & Shrub & Endemic & $\mathrm{VU}$ \\
\hline Trichadenia zeylanica & Achaceaeria & Tree & Endemic & $\mathrm{LC}$ \\
\hline Mangifera zeylanica & Anacardiaceae & Tree & Endemic & $\mathrm{LC}$ \\
\hline Semicarpus gardneri & Anacardiaceae & Tree & Endemic & $\mathrm{LC}$ \\
\hline Semicarpus acuminata & Anacardiaceae & Tree & Endemic & VU \\
\hline Semicarpus marginata & Anacardiaceae & Tree & Endemic & $\mathrm{EN}$ \\
\hline Semicarpus sp & Anacardiaceae & Tree & & \\
\hline Nothopegia beddomei & Anacardiaceae & Tree & Indegenous & $\mathrm{LC}$ \\
\hline Anacardium occidentale & Anacardiaceae & Tree & Indegenous & \\
\hline Lannea coremandelica & Anacardiaceae & Tree & Indegenous & $\mathrm{LC}$ \\
\hline Mangifera indica & Anacardiaceae & Tree & Exotic & \\
\hline Camponosperma zeylanica & Anacardiaceae & Tree & Endemic & $\mathrm{LC}$ \\
\hline Uvaria zeylanica & Annonaceae & Climber & Indegenous & $\mathrm{LC}$ \\
\hline Cyathocalyx zeylanica & Annonaceae & Tree & Indegenous & LC \\
\hline Polyalthia cerasoides & Annonaceae & Tree & Indegenous & LC \\
\hline Polyalthia korinti & Annonaceae & Tree & Indegenous & $\mathrm{LC}$ \\
\hline Xylopia paviflora & Annonaceae & Tree & Indegenous & LC \\
\hline Desmos elegans & Annonaceae & Tree & Endemic & VU \\
\hline Goniothalamus gardneri & Annonaceae & Shrub & Endemic & VU \\
\hline Miliusa indica & Annonaceae & Shrub & Indegenous & $\mathrm{LC}$ \\
\hline Alstonia macrophylla & Apocynaceae & Tree & Exotic & \\
\hline Alstonia scolaris & Apocynaceae & Tree & Indegenous & $\mathrm{LC}$ \\
\hline Ochrosia oppositifolia & Apocynaceae & Tree & Indegenous & VU \\
\hline Pagiantha dichotoma & Apocynaceae & Tree & Indegenous & $\mathrm{LC}$ \\
\hline Leptadenia reticulate & Apocynaceae & Climber & Indegenous & $\mathrm{LC}$ \\
\hline Caryota urens & Arecaceae & Tree & Indegenous & $\mathrm{LC}$ \\
\hline Areca sp & Arecaceae & Tree & & \\
\hline Areca catechu & Arecaceae & Tree & Indegenous & \\
\hline Phoenix pusilla & Arecaceae & Tree & Indegenous & $\mathrm{LC}$ \\
\hline Calamus thwaitesii & Arecaceae & Climber & Indegenous & VU \\
\hline Canarium zeylanicum & Burseraceae & Tree & Endemic & VU \\
\hline Bhesa ceylanica & Celastraceae & Tree & Endemic & $\mathrm{LC}$ \\
\hline Calophyllum inophyllum & Clusiaceae & Tree & Indegenous & $\mathrm{LC}$ \\
\hline Calophyllum bracteatum & Clusiaceae & Tree & Endemic & NT \\
\hline Calophyllum walker & Clusiaceae & Tree & Endemic & VU \\
\hline Garcinia quaesita & Clusiaceae & Tree & Endemic & $\mathrm{LC}$ \\
\hline Garcinia echinocarpa & Clusiaceae & Tree & Indegenous & VU \\
\hline Combretum albidum & Combretaceae & Climber & Indegenous & \\
\hline Terminalia arjuna & Combretaceae & Tree & Indegenous & $\mathrm{LC}$ \\
\hline Connarus championii & Connaraceae & Climber & Endemic & NT \\
\hline Dillenia retusa & Dilleniaceae & Tree & Indegenous & $\mathrm{LC}$ \\
\hline Dillenia triquetra & Dilleniaceae & Tree & Indegenous & $\mathrm{LC}$ \\
\hline Schumacheria castaneifolia & Dilleniaceae & Tree & Endemic & $\mathrm{LC}$ \\
\hline Tetracera sarmentosa & Dilleniaceae & Climber & Indegenous & LC \\
\hline Dioscorea pentaphylla & Dioscoreaceae & Climber & Indegenous & LC \\
\hline Dipterocarpus zeylanicus & Dipterocarpaceae & Tree & Endemic & NT \\
\hline Shorea sp & Dipterocarpaceae & Tree & & \\
\hline Shorea sp. & Dipterocarpaceae & Tree & & \\
\hline
\end{tabular}




\begin{tabular}{|c|c|c|c|c|}
\hline Diospyros insignis & Ebenaceae & Tree & Endemic & NT \\
\hline Diospyros walkerea & Ebenaceae & Tree & Indegenous & VU \\
\hline Diospyros hirusta & Ebenaceae & Tree & Endemic & VU \\
\hline Elaeocarpus serratus & Elaeocarpaceae & Tree & Indegenous & $\mathrm{LC}$ \\
\hline Botanical name & Family & Life form & $\begin{array}{l}\text { Taxonomic } \\
\text { status }\end{array}$ & $\begin{array}{c}\text { Conservation } \\
\text { status }\end{array}$ \\
\hline Hevea brasiliensis & Euphorbiaceae & Tree & Indegenous & \\
\hline Bridelia mooni & Euphorbiaceae & Tree & Endemic & $\mathrm{LC}$ \\
\hline Bridelia retusa & Euphorbiaceae & Tree & Indegenous & $\mathrm{LC}$ \\
\hline Macaranga peltata & Euphorbiaceae & Tree & Indegenous & $\mathrm{LC}$ \\
\hline Aporusa lanceolata & Euphorbiaceae & Tree & Endemic & $\mathrm{LC}$ \\
\hline Chaetocarpus castanocarpus & Euphorbiaceae & Tree & Endemic & $\mathrm{LC}$ \\
\hline Mallotus rhamnifolius & Euphorbiaceae & Tree & Indegenous & $\mathrm{LC}$ \\
\hline Sauropus androgynous & Euphorbiaceae & Shrub & Indegenous & $\mathrm{LC}$ \\
\hline Aporusa lindleyana & Euphorbiaceae & Tree & Indegenous & \\
\hline Erythrozylum zeylanicum & Erythoroxylaceae & Tree & Endemic & $\mathrm{LC}$ \\
\hline Adenanthera pavonina & Fabaceae & Tree & Indegenous & $\mathrm{LC}$ \\
\hline Entada pusaetha & Fabaceae & Climber & Indegenous & $\mathrm{LC}$ \\
\hline Humboldtia laurifolia & Fabaceae & Shrub & Indegenous & $\mathrm{LC}$ \\
\hline Albizia lebbeck & Fabaceae & Tree & Indegenous & NT \\
\hline Acacia mangium & Fabaceae & Tree & Exotic & \\
\hline Archidendron bigeminum & Fabaceae & Tree & Indegenous & $\mathrm{LC}$ \\
\hline Hydnocarpus venenata & Flacourtiaceae & Tree & Endemic & $\mathrm{LC}$ \\
\hline Salacia oblonga & Hippocrateaceae & Tree & Indegenous & EN \\
\hline Stemonurus apicalis & Icacinaceae & Tree & Endemic & NT \\
\hline Litsea longifolia & Lauraceae & Tree & Endemic & $\mathrm{LC}$ \\
\hline Cinnanmomum cassia & Lauraceae & Tree & Indegenous & $\mathrm{LC}$ \\
\hline Cryptocarya wightiana & Lauraceae & Tree & Indegenous & NT \\
\hline Pterospermum suberifolium & Malvaceae & Tree & Indegenous & $\mathrm{LC}$ \\
\hline Osbeckia aspera & Melastomataceae & Shrub & Indegenous & NT \\
\hline Osbeckia octandra & Melastomataceae & Shrub & Endemic & $\mathrm{LC}$ \\
\hline Aphanamixis polystacha & Meliaceae & Tree & Indegenous & $\mathrm{VU}$ \\
\hline Chukrasia tabularis & Meliaceae & Tree & Indegenous & NT \\
\hline Swieteniav mahogoni & Meliaceae & Tree & Exotic & \\
\hline Dysoxylum ficiforme & Meliaceae & Tree & Indegenous & NT \\
\hline Coscinium fenestratum & Menispermaceae & Climber & Indegenous & $\mathrm{LC}$ \\
\hline Artocarpus nobilis & Moraceae & Tree & Endemic & $\mathrm{LC}$ \\
\hline Ficus benghalensis & Moraceae & Tree & Indegenous & $\mathrm{LC}$ \\
\hline Artocarpus incises & Moraceae & Tree & Exotic & \\
\hline Artocarpus heterophyllus & Moraceae & Tree & Indegenous & \\
\hline Ficus exasperate & Moraceae & Tree & Indegenous & $\mathrm{LC}$ \\
\hline Horsfieldia iryaghedhi & Myristicaceae & Tree & Endemic & VU \\
\hline Myristica dactyloides & Myristicaceae & Tree & Indegenous & $\mathrm{LC}$ \\
\hline Horsfieldia irya & Myristicaceae & Tree & Indegenous & $\mathrm{LC}$ \\
\hline Syzygium amphoracecarpus & Myrtaceae & Tree & Endemic & NT \\
\hline Syzygium caryophyllatum & Myrtaceae & Tree & Indegenous & $\mathrm{LC}$ \\
\hline Syzygium rubicundum & Myrtaceae & Tree & Indegenous & $\mathrm{NE}$ \\
\hline Syzygium sp. & Myrtaceae & Tree & & \\
\hline Cleistocalyx operculatus & Myrtaceae & Tree & Endemic & $\mathrm{LC}$ \\
\hline Syzygium gardneri & Myrtaceae & Tree & Indegenous & $\mathrm{LC}$ \\
\hline Syzygium cumini & Myrtaceae & Tree & Endemic & $\mathrm{LC}$ \\
\hline Gomphia serrate & Ochnaceae & Tree & Indegenous & $\mathrm{LC}$ \\
\hline Olax zeylanica & Oleaceae & Tree & Indegenous & $\mathrm{LC}$ \\
\hline Ochlandra stridula & Poaceae & Shrub & Endemic & $\mathrm{LC}$ \\
\hline Piper sylvestre & Piperaceae & Climber & Indegenous & $\mathrm{LC}$ \\
\hline
\end{tabular}




\begin{tabular}{|c|c|c|c|c|}
\hline Ziziphus oenoplia & Rhamnaceae & Shrub & Indegenous & $\mathrm{LC}$ \\
\hline Anisophyllea cinnamomoides & Rhizophoraceae & Tree & Endemic & NT \\
\hline Carallia brachiate & Rhizophoraceae & Tree & Indegenous & NT \\
\hline Canthium rheedii & Rubiaceae & Tree & Indegenous & NT \\
\hline Botanical name & Family & Life form & $\begin{array}{l}\text { Taxonomic } \\
\text { status }\end{array}$ & $\begin{array}{c}\text { Conservation } \\
\text { status }\end{array}$ \\
\hline Gaertnera vaginans & Rubiaceae & Shrub & Indegenous & $\mathrm{LC}$ \\
\hline Morinda citrifolia & Rubiaceae & Tree & Indegenous & $\mathrm{LC}$ \\
\hline Ixora coccinea & Rubiaceae & Tree & Indegenous & $\mathrm{LC}$ \\
\hline Psychotria sarmentosa & Rubiaceae & Climber & Indegenous & NT \\
\hline Wendlandia bicuspidate & Rubiaceae & Tree & Endemic & $\mathrm{LC}$ \\
\hline Acronychia pedunculata & Rutaceae & Tree & Indegenous & $\mathrm{LC}$ \\
\hline Melicope lunu-ankenda & Rutaceae & Tree & Indegenous & $\mathrm{LC}$ \\
\hline Zanthoxylum rhesta & Rutaceae & Tree & Indegenous & $\mathrm{EN}$ \\
\hline Thoddalia asiatica & Rutaceae & Climber & Indegenous & $\mathrm{LC}$ \\
\hline Micromelum minutum & Rutaceae & Tree & Endemic & $\mathrm{LC}$ \\
\hline Flacourtia indica & Salicaceae & Tree & Indegenous & $\mathrm{LC}$ \\
\hline Filicium decipiens & Sapindaceae & Tree & Exotic & $\mathrm{LC}$ \\
\hline Dimocarpus longan & Sapindaceae & Tree & Indegenous & $\mathrm{LC}$ \\
\hline Nephelium lappaceum & Sapindaceae & Tree & Exotic & \\
\hline Sapindus trifoliata & Sapindaceae & Tree & Indegenous & NT \\
\hline Harpullia arborea & Sapindaceae & Tree & Indegenous & VU \\
\hline Pometia pinnata & Sapindaceae & Tree & Indegenous & LC \\
\hline Chrysophyllum roxburghii & Sapotaceae & Tree & Indegenous & NT \\
\hline Mimusops elengi & Sapotaceae & Tree & Indegenous & NT \\
\hline Madhuca longifolia & Sapotaceae & Tree & Indegenous & NT \\
\hline Smilax perfoliata & Smilacaceae & Climber & Indegenous & $\mathrm{LC}$ \\
\hline Symplocos cochinchinensis & Symplocapaceae & Tree & Indegenous & $\mathrm{LC}$ \\
\hline Gyrinops walla & Thymelaeaceae & Tree & Indegenous & VU \\
\hline Grewia carpinifolia & Tiliaceae & Tree & Indegenous & $\mathrm{LC}$ \\
\hline Grewia orientialis & Tiliaceae & Tree & Indegenous & $\mathrm{LC}$ \\
\hline Microcos paniculata & Tiliaceae & Tree & Indegenous & $\mathrm{LC}$ \\
\hline Clerodendrum infortunatum & Verbanaceae & Tree & Indegenous & $\mathrm{LC}$ \\
\hline Stachytarpheta urticaefolia & Verbanaceae & Shrub & Indegenous & \\
\hline Vitex altissima & Verbanaceae & Tree & Indegenous & NT \\
\hline Ampelocissus indica & Vitaceae & Climber & Indegenous & NT \\
\hline \multicolumn{5}{|l|}{ Unidentified 1} \\
\hline \multicolumn{5}{|l|}{ Unidentified 2} \\
\hline Unidentified 3 & & & & \\
\hline
\end{tabular}

\section{Appendix 2}

\begin{tabular}{ll}
\hline Conservation status & Species name \\
\hline Endangered & Semicarpus marginata, Salacia oblonga, Zanthoxylum rhesta \\
\hline Vulnerable & $\begin{array}{l}\text { Semicarpus acuminate, Desmos elegans, Goniothalamus gardneri, Ochrosia } \\
\text { oppositifolia, Calamus thwaitesi, Canarium zeylanicum, Garcinia } \\
\text { echinocarpa, Diospyros walkerea, Diospyros hirusta, Strobilanthes } \\
\text { adenophora }\end{array}$ \\
\hline
\end{tabular}

